\title{
COMPLEXITY, DELAY AND COST - THE COUNTY COURTS IN NORTHERN IRELAND
}

\section{His Honour Judge Hart QC, Recorder of Belfast and Chairman of the Northern Ireland County Court Rules Committee}

Complexity of court procedures, delays in bringing cases to a resolution, and the costs associated with litigation are matters that have been examined and debated over many decades. When Lord Woolf was asked to review the rules and procedures of the civil courts in England and Wales in 1994 this followed no fewer than 60 reports on various aspects of civil practice and procedure published since 1851. ${ }^{1}$ Lord Woolf's reports have brought about a fundamental reshaping and restructuring of the procedures of the civil justice system in England and Wales. It was therefore inevitable that the civil justice system in Northern Ireland, which closely resembles that of England and Wales prior to the implementation of the Woolf reforms, should be subjected to a similar process of review. This took place under the auspices of the Civil Justice Reform Group appointed by the Lord Chancellor in February 1998 under the chairmanship of Lord Justice Campbell. The interim and final reports of the Group have been discussed elsewhere and therefore it is unnecessary to refer to them in detail. ${ }^{2}$ This article considers the issues of complexity, delay and cost in the county courts in Northern Ireland, but before dealing with these topics it is perhaps appropriate to say something about the origin and characteristics of the county courts.

Although the name and structures of the county courts in Northern Ireland imply that they are the same as the county courts in England and Wales, there have long been two fundamental differences between the county courts in Northern Ireland and their counterparts elsewhere in the United Kingdom. The first is that the procedures of the county courts in Ireland have historically been much simpler, based as they are on the "civil bill", a summary procedure which, it would seem, was originally developed by the judges of assize and had become well established in Ireland by the mid seventeenth century. ${ }^{3}$ The second is that since the creation of the county courts in Ireland in their modern form in $1877,{ }^{4}$ the costs of litigation have been regulated by a fixed inter party costs regime under which costs follow the event with the judge having virtually no discretion over the award of costs, and which specifies the costs allowed for solicitor and counsel, so avoiding the need for taxation in all but a handful of cases. These costs are fixed by the County Court Rules Committee and approved by the Lord Chancellor, have statutory force, and take the form of a series of bands

1 The Civil Justice Reform Group Interim Report (April 1999), para 3.1.

2 See Capper, "Keeping Woolf from the Door-the Reform of Civil Procedure in Northern Ireland" (1999) 50 NILQ 434, and "Final Report of the Civil Justice Reform Group - Still Keeping Woolf from the Door" (2000) 51 NILQ 619.

3 D S Greer, "The Development of Civil Bill Procedure in Ireland" in J F McEldowney and P O'Higgins (eds), The Common Law Tradition: Essays in Irish Legal History (Dublin, 1990), pp 27-59.

4 By the County Officers and Courts (Ir) Act, 1877. 
related to the amount awarded in the case of the plaintiff, or claimed in the case of the defendant. A significant recent development has been the creation of a simple, pragmatic, effective and proportionate system of judicial case-management that requires the court to intervene only in the minority of cases that do not proceed to trial within prescribed time limits, which is significantly different to the system of judicial consideration and allocation of every case, however small, which is a feature of the post Woolf litigation landscape in England and Wales.

The simplicity of the proceedings and the fixed scale costs system were described by Lord MacDermott half a century ago:

"In the first place, the procedure is simple and comparatively inexpensive. The civil bill contains a short statement of the relief sought and the nature of the claim. It is served by an official of the court called a process server, and if the defendant wants to defend he or his solicitor so intimates at the office the Clerk of the Crown and Peace. There are no interlocutory proceedings and no pleadings (save in a few special cases), and the case is heard in its turn, on the day indicated in the civil bill or as near thereto as the state of the list allows. The procedure on appeal is equally simple and is a complete rehearing. The costs chargeable throughout are on a fixed scale. This, the absence of interlocutory applications, and the fact that the County Court Judge has no discretion to award costs according to the event, enable the litigant to ascertain, in advance and fairly closely, what his commitments will be, win or lose." 5

Before considering whether these comments are still valid it may be appropriate to briefly describe the present day structure of the county courts, their jurisdiction and the volume of business for which they are responsible. Although it is common to refer to "the County Court" as if it was a single, unified, court like the High Court, this is not strictly accurate. Northern Ireland is divided into seven county court divisions, each of which comprises a group of petty sessions districts, which are in turn based upon the 26 district council areas. For example, the Belfast Recorder's Court (as the county court for the division of Belfast is called) covers Belfast City Council, Newtownabbey Borough Council and Carrickfergus District Council areas. Of the 15 county court judges, four are permanently assigned to Belfast, and one to each of the six divisions outside Belfast. The five remaining judges are peripatetic and allocated to the various divisions as required. The county court jurisdiction is defined in monetary terms, and broadly speaking includes all causes of actions where the amount claimed is up to $£ 15,000$, although in certain categories such as equity, title or probate cases the jurisdiction extends to property with a value of up to $£ 45,000$.

Four full-time district judges also exercise jurisdiction in the county courts. Their jurisdiction is twofold, first of all they have a civil bill jurisdiction,

5 “Law and Practice in Northern Ireland" (1953) 10 NILQ 47 at p 67. 
which has recently been increased to $£ 5,000,{ }^{6}$ and in addition they preside over the small claims court, whose jurisdiction has also been recently increased to $£ 2,000 .^{7}$ One of the district judges is assigned to the division of Belfast and his three colleagues are each responsible for two of the six divisions outside Belfast. In addition to the full-time county court and district judges there are a number of deputy county court judges and deputy district judges. The full-time district judges have all been appointed as deputy county court judges.

Whilst the district judges are concerned exclusively with non-criminal matters, this is not the case as far as county court judges are concerned, who devote a great deal of their time to criminal and other business. In $200040 \%$ of the days sat by county court judges were spent on indictable business in the Crown Court. ${ }^{8}$ In addition they are responsible for hearing appeals from the magistrates' courts in both criminal and civil matters; licensing cases; criminal injury ${ }^{9}$ and criminal damage appeals, and devote a substantial and increasing proportion of their time to work under the Children (Northern Ireland) Order 1995. In 20001005 days were spent on Crown Court work by county court judges, on 228 days the majority of the court's time was devoted to Children Order cases, with a further 71 days where Children Order work was the minority of the court's time. ${ }^{10}$ The effect of these demands upon the time of the county court judges is such that a substantial proportion of ordinary civil business is dealt with by deputy county court judges (who are analogous to recorders or deputy recorders in England and Wales) who sat for 428 days in 2000 , compared to 1512 days sat by county court judges, $22 \%$ of the total. However, as the 1512 days spent on civil business by county court judges includes time devoted to magistrates' courts appeals, licensing cases and criminal injury appeals which are not normally dealt with by deputy judges, it can be seen that the proportion of ordinary civil bill work heard by deputies is appreciably higher than the statistics for days sat by deputy judges would suggest.

Progressive increases in the monetary jurisdiction of the county courts in recent years have resulted in a substantial transfer of litigation from the High Court. This was particularly marked when the jurisdiction, which had been fixed at $£ 5,000$ in 1982 , was increased to $£ 10,000$ in 1992 and to $£ 15,000$ in 1993. The following statistics demonstrate how significant the effect of these jurisdictional increases has been. In 1992 a total of 8143 defended civil bills were dealt with in the county courts, compared to 4368 actions in the Queen's Bench and Chancery divisions of the High Court. ${ }^{11}$ By 2000 16027 defended civil bills were dealt with in the county court, compared to 2141 Queen's Bench, Commercial and Chancery actions in the High Court. ${ }^{12}$ When one bears in mind that in 2000 the district judges also dealt with 9441

${ }^{6}$ From 5 September 2001 by the County Courts (Financial Limits) Order (NI) 2001, SRNI (2001) 67.

7 From 19 March 2001, ibid.

8 Northern Ireland Judicial Statistics 2000.

9 Although this has been replaced by a tariff system from 1 May 2002 under the Criminal Injuries (NI) Order 2002.

10 Northern Ireland Judicial Statistics 2000.

11 Northern Ireland Judicial Statistics 1992.

12 Northern Ireland Judicial Statistics 2000. 
undefended, and 1289 defended, small claims, it can be seen that the county courts, and the small claims courts which are administered by the county court staff, are now the most important courts in terms of volumes of business within the civil justice system in Northern Ireland. Whilst the importance of the small claims courts is clear from these figures, this paper is confined to the working of the county courts.

The last decade has not only seen a very substantial increase in the volume of litigation dealt with by the county courts, but this has been accompanied by a considerable increase in the complexity of many categories of business as the increase in the monetary jurisdiction of the court brings more difficult cases within their ambit, notably professional and clinical negligence, building cases and allegations of discrimination under various statutes, such as the Fair Employment and Treatment (Northern Ireland) Order 1998.

How then do the county courts in Northern Ireland fare when dealing with the interrelated problems of complexity, delay and cost? Although it has been suggested that "Progress and an increase in the financial limits have not allowed the jurisdiction to remain comparatively inexpensive or its procedures simple", ${ }^{13}$ nevertheless the simplicity of the pleadings referred to by Lord MacDermott has been preserved to a considerable extent. Proceedings are still instituted by the plaintiff issuing a civil bill, which remains a simple document in which the plaintiff claims a specific sum, say $£ 7,500$, and sets out the nature of his claim in a few sentences as in a general endorsement on a writ of summons. The defendant indicates that he will contest the case by filing a notice of intention to defend. This does not take the form of a specific denial of each of the plaintiff's claims as in the High Court, but is the equivalent to an appearance in the High Court. It has the effect of putting every aspect of the plaintiff's claim in issue, as the defendant is not obliged, save in extremely limited circumstances, to traverse the plaintiff's claim. On the contrary, the plaintiff must approach the case on the assumption that all aspects of his case have to be proved unless the defendant has admitted any aspects of the claim in open correspondence. This is not necessarily a disadvantage, as Lord MacDermott pointed out:

"When one is not quite certain what the arguments on the other side will be one is usually more alert to investigate the situation comprehensively and to go into Court prepared for any eventuality which a thorough knowledge of the facts and the relevant law may foreshadow. And as a case well made up is generally presented better and more briefly, this stimulus to preparation benefits the court and the litigant as well as the art of advocacy."14

The only further step required by the Rules in every case is that the plaintiff lodge a certificate of readiness stating that the case is ready for hearing and that no interlocutory issues remain outstanding. When this is lodged with the court office the court fixes a date for hearing. In Belfast this is usually four weeks ahead, although outside Belfast where courts do not sit continuously a longer period may elapse.

13 Bell v Dungannon Meats [1996] NI 604 per Campbell J.

14 Supran 5. 
However, in a great many, though by no means all, cases the defendant will serve a notice for further and better particulars on the plaintiff, and the replies delivered by the plaintiff define in greater detail the plaintiff's claim, thereby serving the same purpose as the statement of claim and replies to notice for further and better particulars in the High Court. In many cases the plaintiff will now seek discovery from the defendant by way of an order from the chief clerk. Interrogatories are infrequent. There has undoubtedly been a substantial increase in the number of cases where discovery is sought, and in interlocutory applications to the court, particularly in the past decade. The most common applications to the court are:

1) by the defendant to compel delivery of replies to the notice for particulars by the plaintiff;

2) by the plaintiff to compel compliance with an order for discovery directed to the defendant;

3) by the defendant for disclosure of the plaintiff's medical notes and records; and

4) by the plaintiff for inspection of the scene of the accident by an engineer.

The greater readiness of the parties to resort to interlocutory applications can be seen by the increase of such applications from 3013 in 1997 to 4091 in $2000 .{ }^{15}$ Whilst it has to be accepted that the frequency with which discovery is sought and the burden which this places on the opposite party (usually the defendant), and the practice of serving a notice for particulars, means that the pre-trial procedures are often neither as simple, nor as inexpensive, as they were in 1953, nevertheless the procedures of the county courts are still much simpler than in the High Court. It has to be recognised that when larger amounts are at stake the factual and legal issues will often be of greater complexity than was the case in the past when the jurisdiction was lower, and it is necessary to define the plaintiff's case in a fashion that allows the defendant properly to meet that case. Resorting to a notice for particulars is therefore entirely appropriate in all but the most straightforward cases, and provides a simpler, cheaper but equally effective method of defining the issues than a statement of claim followed by a notice for particulars and replies.

Whilst the increase in the volume of interlocutory applications might be thought to demonstrate the growth of an undesirable form of satellite litigation, this would be an unduly simplistic conclusion for several reasons. First of all, as we shall see, time limits are imposed for the conduct of litigation by the court rules, and a failure by the plaintiff to give replies and so define his case, or by the defendant to give discovery in response to a court order, cannot be ignored by the other side as the clock is ticking inexorably towards a hearing. Whilst it is undesirable that any interlocutory application has to be brought to obtain relief, such applications nevertheless perform an essential function in the case management of the proceedings by the parties, and by the court, to ensure that cases are brought to trial without

\footnotetext{
15 Northern Ireland Judicial Statistics 2000.
} 
delay whenever possible. Secondly, the costs allowed for such applications are extremely modest, which is a disincentive to unnecessary applications.

It is appropriate now to turn to the speed with which proceedings can be dealt with in the county courts. It is common for commentators to refer to "the law's delays" as if these were all the fault of the court. However, it has to be appreciated that a court can only control the pace of litigation through its general procedures, or orders in specific cases, once proceedings have been instituted by the plaintiff. Nevertheless, all too often in the past many cases were not brought to trial as speedily as they ought to have been, and the county courts were no exception. In recent years there have been considerable improvements in the way in which the county courts manage the progress of litigation, improvements which came about as a result of initiatives developed by the county court judges themselves in the early 1990s. These changes have brought much more timely, robust and effective management of litigation in the county courts, with substantial reductions in avoidable delays as a result. This has been achieved by introducing a requirement that the plaintiff serve a certificate of readiness before the case can be set down for hearing, and combining this with a mechanism whereby a failure to lodge the certificate of readiness within the six month period provided by the Rules results in the matter being automatically listed before the judge for further directions, with the court assuming control of the management of the case thereafter.

In the early 1990s the Northern Ireland Court Service set up a working party of practitioners and court officials under the chairmanship of His Honour Judge Russell QC to review a number of aspects of the civil bill system. In 1993 the working party suggested that a number of changes should be made, in particular that provision should be made for the parties to notify the court when a case was ready for hearing by filing a certificate of readiness. At the initiative of the Council of Her Majesty's County Court Judges in Northern Ireland, who were concerned this did not provide a means to enable the court to deal with cases where there were avoidable delays in lodging a certificate of readiness, this proposal was modified to include a requirement that if the certificate of readiness was not lodged by the plaintiff within six months of the lodging of the notice of intention to defend by the defendant, the case would be automatically referred to the judge, who could then give such directions as were necessary to ensure that the case proceeded to trial, including fixing the date for the hearing or dismissing the case. Whilst the judges accepted that there was a need for judicial oversight and control, they considered that the parties should be given a reasonable period of time to prepare for the hearing, and only if they had failed to do so within that period should judicial oversight and control become necessary. As a result of these discussions the County Court Rules were amended by the introduction of Order 8 Rule 3(2):

"In any proceedings in which a notice of intention to defend has been served the Chief Clerk shall, if no certificate of readiness has been delivered to him within a period of six months immediately following the date of service of the notice of intention to defend, list the proceedings before the judge and notify the parties accordingly and the judge may issue such directions concerning the future conduct of any such proceedings as he considers appropriate including, in 
particular, an order that the proceedings be stayed or dismissed."

The period of six months was selected by the judges on the basis of best practice, and represented a pragmatic decision as to what should be allowed as a reasonable period of time after the issue of proceedings before the case would be ready for hearing. Once the notice of intention to defend is lodged it is entered on computer by the court staff and the case is automatically listed for mention if the certificate of readiness has not been lodged in court within six months. The parties are then notified by the court office to appear before the judge, who then holds what is generally referred to as a certificate of readiness callover at which the parties appear and explain why the case is not ready for hearing. Depending upon the reason advanced for the delay in lodging the certificate of readiness, the court will either adjourn the matter to a later date for further review, make any necessary interlocutory order, or set the case down for hearing on a specific date which is sufficiently far in advance to allow the parties time to resolve the outstanding issues. If the case is set down the parties will be given a hearing date and the certificate of readiness has then to be lodged, usually within 14 days. If the plaintiff's solicitor does not appear, or the certificate of readiness is not lodged within the required time, they are again notified to appear before the judge at a later date, and a failure to appear or to satisfactorily explain why the certificate of readiness has not been lodged will normally result in the civil bill being dismissed, although this draconian step has only to be taken in a handful of cases.

This system has the great merit that it only requires judicial oversight and control over those cases which do not proceed to hearing within the time limits provided by the Rules, whilst providing a simple mechanism to enable the judge to case-manage the remainder. Whilst the number of civil bills controlled in this fashion varies from time to time, a minority require judicial intervention. For example, at Belfast Recorder's Court at the end of June 2001 there were 303 cases where no certificate of readiness had been lodged after six months, compared to 1171 where certificates of readiness had been lodged and dates had been given for hearing. In the same court at the end of April 2002 the number of cases where there was no certificate of readiness after six months was 238 , compared to 727 with a certificate of readiness which had been set down for hearing, the difference between the number of cases with a certificate of readiness being due to a substantial fall in the number of civil bills entering the system in the latter part of 2001.

The certificate of readiness procedure has been widely accepted and welcomed by the legal profession and was commended by the Civil Justice Reform Group:

"The Group has no doubt that this system, if properly followed and applied, provides an efficient and pragmatic compromise between judicial intervention and control in every case, and the traditional (and ineffectual) policy of complete reliance upon the observance by the parties of rules of court and the time limits set out in such rules. It is far less demanding of judicial time, and much more flexible, than the universal system of judicial control based upon the 'procedural judge' that has been considered necessary in England and Wales. It avoids the 
imposition of costs upon litigants in every case, but preserves the ability of the judge to manage the case so as to ensure that it is brought to trial as rapidly and effectively as possible in the event that the parties do not prepare the case for trial within 6 months from the case coming into the judicial system." 16

Indeed, the Civil Justice Reform Group recommended that a similar system should be adopted in the Queen's Bench and Chancery Divisions of the High Court. Nevertheless, it also recognised that it "is essential for the efficient and consistent application of the system that the assigned judge for each [county court] division exercise personal control over the callover of cases where the certificate of readiness has not been lodged within 6 months."17 Delegation of this task to a district judge, or a court official, runs the risk that case-management decisions will not be taken with the same degree of authority as should be the case where the decision is made by the assigned judge for the division concerned. It is only where the judge who has ultimate responsibility for the disposition of the business makes such decisions that the system will function as effectively as possible, a view implicitly endorsed by the Civil Justice Reform Group in its recommendation that where the case is not set down for trial within the prescribed period in either the Queen's Bench or Chancery divisions "the matter should be automatically listed before the Senior Queen's Bench judge or the Chancery judge, as appropriate". ${ }^{18}$

The cost of legal proceedings is always a source of controversy. In his Interim Report Lord Woolf began the chapter dealing with costs by saying that "The problem of costs is the most serious problem besetting our litigation system."19 In his final report he said that his recommendations were intended to:

"(a) reduce the scale of costs by controlling what is required of the parties and the conduct of proceedings;

(b) make the amount of costs more predictable;

(c) make costs more proportionate to the nature of the dispute;

(d) make the court's powers to make orders as to costs a more effective incentive for responsible behaviour and a more compelling deterrent against unreasonable behaviour;

(e) provide litigants with more information as to costs so that they can exercise greater control of the expenses which are incurred by their lawyers on their behalf." 20

The inter-party costs regime in the county courts is governed by Order 55 of the County Court Rules and its characteristics were described by Sir Robert Carswell LCJ in $R e C \& H$ Jefferson:

"The structure of the provisions relating to costs is that in the very large majority of cases scale fees are payable both

16 Final report, para 65.

17 Ibid.

18 Final report, para 96.

19 Access to Justice, Final Report, p 78.

20 Ibid, pp 78-79. 
between party and party and between solicitor and client. They are fixed from time to time by the County Court Rules Committee and have statutory force. When the scales are applied there is no element of discretion and taxation of costs and fees is not required. They are largely related to the amount of stake in the proceedings and operate on the swings and roundabouts principle: in some cases solicitors and counsel may be fairly handsomely paid for a case which has not involved at great expenditure of time and effort, in others they may have to do a great deal of work for very modest reward. The virtue of fixed scales is two fold. If the scales are fixed at a suitable level proceedings in the County Court can be conducted at reasonable cost, while giving a reasonable return to the practitioners who conduct them. At the same time the costs of litigation is predictable because it is capable of fairly precise calculation and a prospective litigant may ascertain his financial commitment before he launches proceedings."

Later he referred to the county court as ". . . a court in respect of whose proceedings the costs and fees should be both moderate and ascertainable." ${ }^{21}$

It will be seen from these remarks that the county court system of fixed scale costs meets several of Lord Woolf's objectives. Lord Woolf recognised that "The only way to limit the costs of a case is to limit the amount of work that a solicitor has to do on the case". ${ }^{22}$ By fixing the costs at a suitable level related to the amount claimed the scales ensure that the costs are proportionate to the amounts involved, and that there is no reward for lawyers who conduct litigation in an ineffective or extravagant fashion, because if they spend more time on the preparation of the case than is allowed by the appropriate scale they cannot recover those costs.

A further virtue of the fixed scale costs system is that it avoids the need for taxation, itself a time-consuming process which inevitably creates further expense because of the time spent in preparing the bills for taxation, judicial time spent in determining the costs and the financial cost to the lawyers who do not receive the fees they are entitled to for an appreciable period after the conclusion of the case, and therefore are having to carry the cost of funding the litigation, not just their own costs but the outlays in the form of expert witnesses' fees and court fees which have been incurred on behalf of their clients. This is of particular significance in Northern Ireland where plaintiffs are not expected to meet the costs of litigation until the end of the case. As scales embody the swings and roundabouts principle it is inevitable that they cannot provide for the circumstances of every individual case, but provided the overall returns to practitioners are fair and reasonable the very considerable advantages of fixed scales to both the public and the legal profession are obvious.

However, because of the increased jurisdiction of the county courts and the increasing complexity of county court litigation, for some time the legal profession has argued that the costs allowed by the scales do not provide fair

21 [1998] NI 404 at p 409.

22 Access to Justice, Final Report, p 26 
and reasonable remuneration, and have sought changes in the scales. It became apparent to the Rules Committee from submissions made to the Civil Justice Reform Group that there were areas of concern which required to be addressed, and the Rules Committee indicated to the profession in August 1999 that it proposed to conduct a major review of the county court cost structure once the government's response to the Civil Justice Reform Group's final report was known. The Lord Chancellor announced his broad acceptance of the recommendations of the Civil Justice Reform Group on 16 January 2001, and shortly thereafter the Rules Committee embarked upon a major review of the county court costs structure. Following the precedent of the Civil Justice Reform Group the Rules Committee decided to seek views from a wider range of consultees than had been customary in the past and, having extended the time for submissions at the request of a number of professional bodies, has carried out an intensive, comprehensive and thorough review of every aspect of the scales and the relevant rules over several months, and at the time of writing its deliberations are almost complete.

However, much of the cost of litigation in Northern Ireland, as elsewhere, is not solely due to the legal costs incurred but to the costs incurred by the parties retaining expert witnesses, often when the necessity for doing so is questionable. This has been a cause for judicial concern for some time. In Liddle v Middleton ${ }^{23}$ Stuart Smith LJ observed:

"There has been a regrettable tendency in recent years in personal injury cases, both road traffic and industrial accidents, for parties to enlist the services of experts, whether they are necessary or not. When they are not necessary, they simply add to the already high costs of litigation and the length of the trial. In industrial accidents an expert may well be needed to inspect complicated machinery or to give evidence of practice and safety procedure. But in road traffic accidents it is the exception rather than the rule that expert witnesses are required."

These comments are equally apposite in Northern Ireland and have to be borne in mind in a number of contexts. First of all, where an application is made for inspection under Order 14 Rule 9(1) the Court has a discretion whether to grant inspection as it is required to be satisfied that the inspection "may be necessary or expedient for the purpose of obtaining full information or evidence." Those deciding whether to retain a consulting engineer, and the court in deciding whether or not to grant an order for inspection, should consider carefully the issue(s) to which the evidence of the expert witness is thought to be relevant to see whether the facts which need to be proved in support of the plaintiff's case can be established in a more economical and equally satisfactory manner than by retaining a consulting engineer to carry out an inspection of the location of the accident, preparing a plan, and taking photographs.

However, even where an inspection has been justifiably carried out and an engineer has prepared a report, efforts should be made to avoid incurring the

23 [1995] PIQR 36. 
costs of the engineer's attendance by seeking agreement that the report be admitted in evidence without the maker attending. Such efforts seem to be rarely made, or if they are made, to be successful. If necessary an application should be made to the court under Order 24 Rule $2 \mathrm{~B}(3)$ to have the report of the expert witness admitted if the witness is not available on the date fixed for hearing. Such orders are now commonly made in the county courts and help to reduce the cost of litigation, as well as avoiding unnecessary adjournments.

Under Order 55 Rule 6 of the County Court Rules the judge in the county court exercises the power of the taxing master in respect of witnesses' expenses. If there is a dispute as to whether it was appropriate to either engage an engineer (or other expert witness), or to call the witness at the trial, or as to the fees to be allowed to the witness, the court may well take the view that some or all of the costs of a consulting engineer may not be properly allowable against the losing party, even if the consulting engineer was retained on counsel's direction, on the basis that it was not reasonable to incur such costs because they were neither necessary nor proper to establish the successful party's case if the facts sought to be proved by the engineer could have been established in a more economical fashion.

It would be wrong to suggest that the unnecessary attendance of professional witnesses only arises where engineers are involved, and in recent years there has been a much greater readiness on the part of county court judges to resort to Order 24 Rule $2 \mathrm{~B}(3)$ to admit the evidence of medical witnesses whose reports cannot be agreed. Whilst there will clearly be cases where it is necessary for the court to hear the oral evidence of medical experts who are in dispute as to the cause or extent of a plaintiff's injuries to do justice to the parties, nevertheless where a thorough and comprehensive report has been prepared justice can generally be done by admitting the report in evidence, thereby avoiding the additional expense incurred by the parties in requiring the attendance of the doctor(s), and the consequent dislocation of the work of the hard-pressed medical profession in the National Health Service.

Nevertheless, there remain a number of areas where the costs of expert witnesses require to be addressed. In its Final Report the Civil Justice Reform Group addressed this issue:

"The Group has consistently emphasised the importance of proportionality in civil litigation. It would appear that the greatest threat to proportionality in the County Courts is not the cost of the legal fees but rather the cost of expert witnesses, in particular engineers. Although informal scale fees have been agreed for such witnesses though liaison between the Legal Aid Department and the professional bodies, these often dictate hourly rates rather than block amounts with the result that it is not unusual for expert's fees to be entirely disproportionate to the value of the claim. The Group hopes that this class of cost will diminish as the result of its other proposals, such as its encouragement of the use of joint experts and the use of written as opposed to oral evidence. However, it has concluded that more fundamental action is required to address this long established problem. Accordingly, the Group recommends that the County Court Rules Committee ought to 
have regard to the provision of scale fees for experts, to be formulated after consultation with the relevant professional bodies." 24

The Rules Committee will, no doubt, wish to consider this question when it completes its review of the existing costs scales.

From this review of the working of the county courts in Northern Ireland it will be apparent that whilst their procedures may no longer embody the pristine simplicity of half a century ago, in large measure this is because their jurisdiction and workload have greatly increased. Nevertheless their procedures are still relatively simple, and they continue to enjoy a system of fixed costs which confers real advantages on both the public and the legal profession. A simple but effective system of case management has been devised and put in place, and is applied only to the minority of cases which fail to proceed to trial within a reasonable time frame. Although the contribution of the county courts to combating the problems of complexity, delay and cost in the civil justice system in Northern Ireland has been considerable, it would be foolish to assume that the system is perfect in every respect and cannot be improved. Much remains to be done. Those recommendations of the Civil Justice Reform Group which directly relate to the county courts, or will have an impact on civil litigation generally, such as the adoption of pre-action protocols and changes in the rules governing discovery, have still to be implemented. The Rules Committee will have to grapple with the complex issue of costs of expert witnesses, either by encouraging the use of agreed experts, a development which appears to be one of the early successes of the Woolf reforms in England and Wales, or by developing scales of costs for expert witnesses, or both. The listing of civil cases; the effective use of judicial time; the impact of other categories of work upon the time available for county court judges to hear civil bill business, and the need for the widespread use of deputy judges as a result, are just some of the areas where changes may be necessary in order to ensure that the county courts continue to provide a high level of service to the litigants who resort to them.

\footnotetext{
24 Final Report, para 82.
} 